ANDREW H. SMTTH† \& JOHN ROTHER††

Americans long ago dedicated themselves to the removal of social and economic barriers that unfairly burdened racial and ethnic minorities, women, and older people. Discrimination against individuals on the basis of their membership in artificially defined groups was rejected. The current crisis in health care expenditures, however, may be reviving some old prejudices and creating new ones, particularly against older people. Questions have been raised about older Americans, their place in society, and their rightful claim on resources such as health care. The way that society addresses these questions may well determine the character and quality of life in this country over the next few decades.

\title{
I. The Problem
}

There is a broad consensus that cost containment efforts of the 1980 s designed to stem the rising tide of health care expenditures were failures for the most part, and that the American economy cannot sustain the level of growth in expenditures that marked the decade. National expenditures for health care rose at an average annual rate of $10.4 \%$ between 1980 and 1990; as a share of the gross national product, these expenditures rose from $9.1 \%$ to $12.2 \%$ over that period. ${ }^{1}$ Medicare expenditures increased at an even higher $11.8 \%$ average rate. ${ }^{2}$ Health insurance costs to employers rose by 46.3\% between 1988 and $1990 .^{3}$ Despite these enormous expenditures, there are today approximately thirty-four million people without even basic health insurance coverage, ${ }^{4}$ and there is little

† Research Analyst, Public Policy Institute, American Association of Retired Persons. J.D., 1987, Case Western Reserve University.

t† Director, Division of Legislation and Public Policy, American Association of Retired Persons. J.D., 1975, University of Pennsylvania.

${ }^{1}$ Joshua M. Wiener, Rationing in America: Overt and Covert, in RATIONING AMERICA's Medical CARE: THE OREGON PLAN AND Beyond 12, 13 (Martin A. Strosberg et al. eds., 1992).

2 See OFFICE OF MGMT. AND BUDGET, Budget OF THE UNTTED STATES GOVERNMENT: FisCal Year 1992, H.R. Doc. No. 3, 102d Cong., 1st Sess. pt. 7, at 43-44 (1991).

${ }^{3}$ Frank Swoboda, Health Care Costs Climb 21.6\% in '90, WASH. POST, Jan. 29, 1991, at D1.

1 Richard D. Lamm, Columbus and Copernicus: New Wine in Old Wineskins, 56 MOUNT SINAI J. MED. 1, 4 (1989) [hereinafter Wineskins]. 
evidence that Americans are healthier than citizens of other Western industrialized countries that spend far less on health care. ${ }^{5}$

The failure of cost containment efforts instituted by governments and employers to control health care cost inflation ${ }^{6}$ has propelled the discussion of explicit rationing of beneficial health care services from the halls of academe to the center of the health policy debate. Proponents of rationing believe that cost containment short of rationing is doomed to failure and see unbridled patient demand, the aging of society, and the onward rush in medical technology development as factors converging to produce an economic catastrophe. ${ }^{7}$ They maintain that disaster may be averted only if policymakers face the painful truth that mandates the development and implementation of some form of explicit rationing of health care services. ${ }^{8}$ Some maintain that there are both economic and moral imperatives to ration some health care services by age. ${ }^{9}$ This makes the debate especially relevant to and poignant for older Americans.

\section{Medical CARE for the Elderly as an Alleged Source OF THE HEALTH CARE EXPENDITURE GRISIS}

Increasing patient demand for services has been identified by proponents of rationing as a major source of rising health care costs. ${ }^{10}$ Available empirical evidence casts some doubt on this

${ }^{5}$ See Paul Greenberg, A Health Plan Where Less Becomes More, GHIC. TRIB., Nov. 22, 1991, at 25; Richard D. Lamm, The U.S. Has Got to Ration Health Care, NEwSDAY, Oct. 25,1991 , at 57 .

${ }^{6}$ These included the imposition of prospective payment, increased coinsurance and deductibles, the development of preferred provider organizations, the fostering of health maintenance organization membership, and the imposition of managed care through utilization review, second opinion programs, and prior authorization requirements. See Wiener, supra note 1 , at 14 .

7 See, e.g., HENRY J. AARON \& WILlIAM B. SchWARTZ, The PAINFUl PRESCRIPTION: Rationing Hospital Care 13 (1984); Daniel Callahan, SETTING limits 15-24 (1987) [hereinafter SETTING LIMITS]; DANIEL CALLAHAN, WHAT KIND OF LIFE? 20-26 (1990) [hereinafter WHAT KIND OF LIFE]; Richard D. Lamm, Brave New World of Health Care, 52 ANNALS OF THORAGIC SURGERY 369-84 (1991) [hereinafter Brave New World]; Wineskins, supra note 4, at 1-10; Richard D. Lamm, The Ten Commandments of an Aging Society, 54 VITAL SPEECHES 133, 134 (1987); Lester C. Thurow, Learning to Say 'No', 311 NEw ENG. J. MED. 1569, 1570 (1984).

${ }^{8}$ See SETTING LIMITS, supra note 7, at 20-23; Wineskins, supra note 4, at 4; see also NORMAN DANIELS, AM I MY PARENTS' KEEPER? AN ESSAY ON JUSTICE BETWEEN THE YOUNG AND THE OLD 83-102 (1988) (arguing that rationing life-extending resources by age is a fair distributive technique).

9 See DANIELS, supra note 8, at 91; Wineskins, supra note 4 , at 7 .

${ }^{10}$ See WHAT KIND OF LIFE, supra note 7, at 105, 117; Brave New World, supra note 
assertion. In a study of hospital usage patterns in Boston and New Haven, researchers found (after controlling for patient differences) that Bostonians used 4.5 beds per thousand population, while the citizens of New Haven used fewer than 3 beds per thousand. ${ }^{11}$ Boston's per capita expenditures for hospitalization were found to be consistently twice those for New Haven. ${ }^{12}$ Most of the difference in resource use was found to be associated with medical conditions for which there is a high variation in use rates and for which physicians' clinical decision thresholds for hospitalization depend on the supply of beds. ${ }^{13}$ Of course, patients may be more demanding than in the past, but it is difficult to reconcile the view that patient demand is of primary importance in rising health care expenditures with the findings in the Boston-New Haven use pattern study. Are the citizens of New Haven less demanding than residents of Boston, or do physicians in Boston hospitalize more aggressively? What is apparent is that we really know very little about patient demand, and that it may thus be inappropriate to predicate policy changes upon such an assumption. ${ }^{14}$

The aging of American society, with its associated increases in morbidity and health care costs, ${ }^{15}$ is viewed by some as the most important component of a discouraging health care expenditure picture. ${ }^{16}$ A number of commentators argue that the most appropriate place to ration care is with the elderly, and propose to restrict expensive, high technology, life-sustaining care for those who have reached a certain age. ${ }^{17}$ It is assumed that this type of care

7, at $\mathbf{3 7 0 .}$

${ }^{11}$ See John E. Wennberg, The Road to Guidelines, 13 HeALTH MGMT. Q., Second Quarter, at 1, 6 (1991).

${ }_{12}$ See id.

${ }^{13}$ See id. But see Miron Stano, Further Issues in Small Area Variations Analysis, 16 J. HEALTH POL. POL'Y AND L. 573, 584 (1991) (attributing the difference in resource use to patient preferences and diffusion of information and technology which are not well understood).

${ }^{14}$ See John Wennberg, Outcomes Research, Cost Containment and the Fear of Health Care Rationing, 323 NEW ENG. J. MED. 1202, 1202 (1990) (noting the lack of knowledge concerning patient demand).

${ }^{15}$ For a discussion of the aging of the population, the growth in the number of the "older old," and the resulting consequences for health care expenditures, see Dennis W.Jahnigen \& Robert H. Binstock, Economic and Clinical Realities: Health Care for Elderly People, in TOO OLD FOR HEALTH CARE? CONTROVERSIES IN MEDICINE, LAW, ECONOMICS, AND ETHICS 13, 17-22 (Robert H. Binstock \& Stephen G. Post eds., 1991) [hereinafter TOO OLD FOR HEALTH CARE?].

${ }^{16}$ See SETITNG LIMITS, supra note 7, at 115-58; Wineskins, supra note 4, at 6-8.

${ }^{17}$ See SETTING Limis, supra note 7, at 115-58; Wineskins, supra note 4, at 6-8. 
represents an investment of scarce resources with few returns, frequently involving intensive and aggressive treatment that serves only to prolong the agony of dying. ${ }^{18}$ It is also assumed that vast resources are being expended, and are destined to be spent, on such care for the dying elderly. ${ }^{19}$ This perception is bolstered by a study that shows that a large amount of money is expended on Medicare beneficiaries in their last year of life. ${ }^{20}$

Researchers examining data from 1978 found that the less than $6 \%$ of Medicare beneficiaries who died in that year accounted for approximately $28 \%$ of Medicare expenditures. ${ }^{21}$ This proportion of expenditures may, intuitively, seem excessive. Intuition, however, is not a dependable guide. First, it is worth noting that the share of the Medicare budget devoted to elderly people in their last year of life has been nearly constant since the inception of the program. ${ }^{22}$ Second, even if it were possible to predict with certainty which patients would die within twelve months (something which cannot be done), and all care were to be withheld from these beneficiaries, relatively small savings would be achieved; only 22.7 billion dollars, or $4.6 \%$ of health care expenditures, would have been saved in 1987. ${ }^{23}$ Those who advocate age-based rationing do not generally propose to withhold all medical treatment from older persons, but rather, expensive, aggressive care. Researchers have found that only $3 \%$ of Medicare decedents incur "high costs." 24 Withholding all treatment for high-cost Medicare decedents would have produced savings of 2.8 billion dollars in $1987 .{ }^{25}$ This is not a negligible amount of money, but saving this sum would have produced little of economic significance in the context of health care expenditures that reached nearly one half of a trillion dollars. ${ }^{26}$ It is also important to note that of high cost patients included in the 1984 study, over one half survived. ${ }^{27}$ If high cost health care had been

18 See Wineskins, supra note 4, at 6-8.

19 See id. at 7.

${ }^{20}$ See James Lubitz \& Ronald Prihoda, The Use and Costs of Medicare Services in the Last 2 Years of Life, 5 HEALTH CARE FIN. REV. 117, 117-31 (1984).

${ }^{21} \mathrm{See} i d$. at 117 .

22 See id.

${ }^{23}$ See Jahnigen \& Binstock, stupra note 15, at 29-30.

24 See Lubitz \& Prihoda, supra note 20, at 122. "High cost" in the Lubitz and Prihoda study refers to Medicare patients with reimbursements of $\$ 20,000$ or more in 1978. See id.

${ }^{25}$ See Jahnigen \& Binstock, supra note 15 , at 30 .

26 See id.

27 See Lubitz \& Prihoda, supra note 20, at 122. 
withheld from this group of once seriously ill people, a fraction of one percent in total health care expenditures could have been saved, but at the price of many lives.

Underlying the debate over rationing life-sustaining care for older persons is the image of frail, moribund, elderly patients being shocked back to life twenty or thirty times, being subjected to all the wonders of modern medical science, before finally being allowed to die. ${ }^{28}$ This image does not, however, accurately depict how such patients are commonly treated. In fact, aggressive treatment of the elderly decreases as the level of impairment increases. ${ }^{29}$ Frail, totally impaired patients do not routinely receive expensive, high technology medical treatment. They receive supportive care primarily, which in itself proves quite expensive. ${ }^{30}$

It has been argued that if we look not at the current situation, but at trends in aging, we shall see that a vastly expanded population of "older old" in the more distant future, coupled with advances in life-sustaining technology, will inevitably overwhelm and destroy our economy. ${ }^{31}$ There is cause for concern, but the policy proposed, to set age limits for life-sustaining care, hardly exhausts the possible policy alternatives to meet the challenge of an aging society and rapidly increasing very old population. One alternative would be to increase outlays for research to prevent or effectively treat diseases of old age that create the greatest need for long term care. ${ }^{32}$ The incidence of Alzheimer's disease, Parkinson's disease, osteoarthritis, and osteoporosis increases exponentially with age, and each produces lengthy periods of disability requiring years of long term care. ${ }^{33}$ Despite the fact that current and projected costs

${ }^{28}$ Wineskins, supra note 4 , at 6.

${ }^{29}$ See Anne A. Scitovsky, Medical Care in the Last Twelve Months of Life: The Relation Between Age, Functional Status, and Medical Care Expenditures, 66 MILBANK Q. 640, 649-56 (1988).

${ }^{30}$ See id.

31 See Wineskins, supra note 4, at 1-2. Daniel Callahan writes:

Right now, the very old do not receive a great deal of high-technology medicine. However, the trend is clearly in that direction, with a constant upward swing in the number of treatments and procedures originally developed for younger patients being applied to elderly patients. Pursuit of that course ... will surely divert money from the health and other needs of younger age groups.

Daniel Callahan, Old Age and New Policy, 261 JAMA 905, 906 (1989).

32 See Edward L. Schneider, Options to Control the Rising Health Care Costs of Older Americans, 261 JAMA 907, 908 (1989).

${ }^{33}$ See id. 
associated with these diseases are enormous, federal research funds have been slow in coming; they are still only a small fraction of the overall spending for these diseases. ${ }^{34}$ The prevention of these and other diseases associated with advanced age could significantly improve prospects for future health care expenditures. To suggest that these diseases cannot be conquered, or that should they be overcome they would simply be replaced by others that would similarly affect the elderly with equally high expenditures, is unfounded pessimism. ${ }^{35}$

\section{JUSTIFICATIONS FOR Age-BASEd RATIONINg PROPOSALS}

Arguments in favor of age-based rationing are founded on more than economics. Medical benefit, productivity, equality, natural life-span, and intergenerational justice are just a few of the bases cited in support of age-based rationing. ${ }^{36}$

The medical benefit argument asserts that older people cannot, because of their physical condition, benefit from certain treatments. While it is true that advanced age is statistically associated with reduced likelihood of a favorable medical outcome, it is, as a single factor, a highly undependable clinical outcome predictor. ${ }^{37}$ In fact, physiologic age does not correlate at all well with chronological age. Older people are extremely heterogeneous, both physiologically and psychologically-more so than younger adults. ${ }^{38}$. For this reason, an arbitrary age-based cutoff for certain medical services is

34 See id.

${ }^{35}$ See id. As we look at the history of medicine in the twentieth century, we find that there is more reason for optimism than pessimism. It is a history of remarkable progress, and there is little reason to suppose that curative and preventative discoveries will not continue. Current research in genetics, for example, could produce extraordinary advances in human health and longevity. See, e.g., Francesca Happe, Aging Problem "Can be Solved, "DaILY Telegraph (London), Feb. 17, 1992, at 10 (London) (discussing the findings evolutionary biologist Dr. Michael Rase presented in a paper to the American Association for the Advancement of Science).

${ }^{36}$ See RoBERT H. BLANK, RATIONING MEDICINE 189 (1988) (medical benefit); SETTING LIMTTS, supra note 7, at 66-67 (natural life span); Raymond A. Belliotti, Moral Assessment and the Allocation of Scarce Medical Resources, 5 VALUES AND ETHICS IN HEALTH CARE 251, 251-62 (1980) (productivity); Lamm, The Ten Commandments of an Aging Society, supra note 7, at 136 (intergenerational justice); Robert M. Veatch, Justice and Valuing Lives, in LIFE SPAN 197, 197-224 (Robert M. Veatch ed., 1979) (equality);

${ }^{37}$ See Jahnigen \& Binstock, supra note 15, at 26.

${ }^{38}$ See JAMEs F. Fries \& LAWRENCE M. CRAPO, VitAlitTy AND AgING 108-09 (1981); Nathan W. Shock et al., Normal Human Aging: The Baltimore longitudinal STUDY OF AGING 1 (1984). 
inappropriate if the goal is to target treatments to those who can benefit from them.

Some would justify the withholding of expensive medical services to older persons on the basis of the decreased productivity of the elderly. ${ }^{39}$ Such commentators implicitly question what return society will realize from its investment in care, particularly life-sustaining care, for the older persons. Some may argue that excluding older persons from treatment could result in greater returns for society, were those dollars invested in more "worthy," productive workers. This view presents a demeaning, monetary vision of the value of human life that is not acceptable in an egalitarian society. If we believe that all human life is sacred, and equally deserving of protection, then access to care should not be determined by what society may gain from permitting an individual to regain her health. ${ }^{40}$

Restrictions on health care services to older Americans have been suggested to follow from application of the "principle of equality" to health care spending. This suggestion is based upon the idea that individuals should have the opportunity to live to the same age as others-that there is a prima facie right to a minimum number of life-years. ${ }^{41}$ This perspective, as some formulate it, would support limitation of health care for the elderly to provide services that would allow all, to the extent possible, to reach at least a certain age. ${ }^{42}$ Here persons are treated as sums of life-years, not as individual human entities; individuals' lives are not recognized as equally, but uniquely, precious.

Perhaps the most widely discussed justification for rationing lifesustaining health care for the elderly is the "natural life-span" view articulated by Daniel Callahan. ${ }^{43}$ He argues that the cost of health care for the elderly will inevitably deprive younger generations not only of adequate health care, but of many other things they need to realize their full life experience. ${ }^{44}$ Callahan calls for a policy-agebased rationing-that will allow young people the opportunity to become old, proceeding along the following lines. ${ }^{45}$ The elderly

${ }^{39}$ See JOHN F. KILNER, Who LIVES? WHO DIES? 79-80 (1990).

${ }^{40}$ See id. at 90.

41 See id. at 83-84.

42 See id.

${ }^{43}$ See Daniel Callahan, Health Care Struggle Between Young and Old, SOcIETY, Oct. 1991, at 29, 30-81 (1991).

11 See id. at 30 .

${ }^{45}$ See id. 
know that much of their own welfare depended upon the work and contributions of earlier generations. They should not place the young in the difficult position of forcing them to make sacrifices. The elderly should lead the way, and allow the needs of the young to take precedence over their own needs. Callahan describes this state of affairs as "both gracious and fair." 46

Callahan advances the notion of a "natural lifespan," a lifespan that is normative rather than just a statistical average. ${ }^{47} \mathrm{He}$ defines the natural lifespan as "one in which life's possibilities have on the whole been achieved and after which death may be understood as a sad, but nonetheless relatively acceptable event." ${ }^{48}$ Once one has lived this natural lifespan, roughly figured to be about the late seventies or early eighties, one should not receive expensive, life sustaining medical treatment. Callahan proposes that those who continue to live on past the natural lifespan should receive only supportive and palliative care. ${ }^{49}$

The concept of a "natural life-span" is hard to defend in an age when so many people continue to lead active and healthy lives at age eighty and older. To attempt to establish an age at which everyone will have accomplished everything of significance is, inevitably, a hopeless enterprise. As noted above, the older population is far too heterogeneous to permit such a calculation, unless one is prepared to completely ignore individual human potential. One need only note the activities and accomplishments of such octogenarians and nonagenarians as Bertrand Russell, ${ }^{50}$ Pablo Picasso, ${ }^{51}$ Isaac Bashevis Singer, ${ }^{52}$ Konrad Adenauer, ${ }^{53}$

$46 I d$. at 31 .

47 See SETTING LIMITS, supra note 7, at 66 (arguing that biographical, not biological, events should be used to determine what is, or is not a "tolerable death" and therefore, when a "natural life span" has been reached).

$48 I d$.

${ }^{49}$ See id. at 76-78.

${ }^{50}$ Bertrand Russell (1872-1970), British philosopher, published Political Ideals in 1963, when he was 91 years old. Russell established the Bertrand Russell Peace Foundation and the Atlantic Trust in 1963, and worked actively in opposition to United States policy in Vietnam until shortly before his death at age 97.

${ }^{51}$ Pablo Picasso (1881-1973), between the ages of 85 and 90 , produced three celebrated series of works, including hundreds of drawings, engravings, and paintings. Critics hailed them as possessing unprecedented freshness.

52 Isaac Bashevis Singer (1904-1991), Nobel Prize laureate, continued to write until shortly before he died. He published The Image when he was 81, and The Death of Methuselah in 1988, at the age of 84.

${ }^{53}$ Konrad Adenauer (1876-1967) was chancellor of the Federal Republic of Germany from 1949-1963. He stepped down from that post in 1963, at the age of 
and many others to doubt the wisdom of restricting medical treatment for those who have lived past their "natural life-span."

Callahan's approach views life as a matter of what one does-the tasks one completes. But this view is quite limited. It has been observed that life may be as much about being as doing, that life may "consist as much of relating to others as of completing tasks. ${ }^{\text {"54 }}$

Finally, the argument for age-based rationing as a matter of intergenerational justice, as drawn by Callahan, Lamm, and others, is unduly one-sided. As Thomasma observes, "intergenerational justice cuts both ways." ${ }^{55}$ It is the elderly, who through their investment of "human capital," who through their sacrifices, created the vast range of resources and services younger people now enjoy. ${ }^{56}$ Greene aptly notes that any economic analysis that takes into account the elderly's investment in human capital would find that they have received less than a competitive return on their investment. ${ }^{57}$ We might well ask what kind of justice it is that would deprive elderly citizens of the results of medical research when their taxes financed those discoveries, and their personal sacrifices (such as those made in America's wars) preserved our opportunity to gain the rewards of a free and prosperous society. ${ }^{58}$

87, after which he wrote his four volume autobiography, Erinnerungen (1965-1968). 54 See KILNER, supra note 39, at 84.

55 David C. Thomasma, From Ageism Toward Autonomy, in TOO OLD FOR HEALTH CARE? supra note 15, at 146.

${ }^{56}$ See Vernon L. Greene, Human Capitalism and Intergenerational Justice, 29 THE GERONTOLOGIST 723, 724 (1989). Greene explains that human capital embodies those capabilities that arise from the possession of a sophisticated stock of knowledge, skills, and accompanying attitudes that are-conducive to producing wealth .... [I]t is called "capital" because it represents an investment-somebody had to sacrifice current consumption . . . in order to create it .... Someone then had to massively fund, both through tax payments and private purchase, the entire structure of public and private education through which this human capital is created and maintained. In short, someone had to invest massively from their incomes and opportunities in order to create the stock of human capital from which most of our current wealth arises.

Id.

${ }^{57}$ See id.

${ }^{58}$ See Thomasma, supra note 55, at 146. 


\section{CONCLUSION}

Rationing high technology, life-sustaining treatment for the elderly would not significantly curtail the growth of health care expenditures. There is little reason to suppose that rationing would avoid the problem of provider-generated revenue protection practices, such as increasing the volume of covered services. ${ }^{59}$ Further, even if money were "saved," there is no reason to believe that it would be dedicated to purposes more constructive that current purposes. ${ }^{60}$ Thus, age-based health care rationing would not achieve the practical goals articulated by its proponents. Further, the social costs of such a policy would be unacceptably high. As Levinsky observes, it would require a societal reeducation program that would excite tensions between the generations, and further devalue the status of older people. ${ }^{61}$

Access to health care should be considered, as it has been widely recognized to be, a right, grounded in fundamental human need. ${ }^{62}$ It is morally unacceptable to ration beneficial health care except in the most extreme situations, and certainly unjustifiable under current circumstances. Rationing is acceptable only where real scarcity exists, where competing fundamental needs might dictate that health care services be withheld in favor of even more urgent needs. Rationing should be the very last option to be considered, and then it should be applied fairly and equitably on the basis of individualized assessment-not according to some artificial criterion such as age or social status. ${ }^{63}$

${ }^{59}$ See Arnold S. Relman, The Trouble with Rationing, 323 NEW ENG. J. MED. 911, 912 (1990).

${ }^{60}$ As Wiener points out, the United States does not have a fixed budget for national health care spending. It is thus impossible to say where money saved through health care spending constraints would go. "[I]t is difficult to say no to additional resources for patients because there is no certainty that the funds will be put to better use elsewhere." Wiener, supra note 1, at 15.

${ }^{61}$ See Norman G. Levinsky, Age as a Criterion for Rationing Health Care, 322 NEW ENG. J. MED. 1813, 1815 (1990).

${ }^{62}$ A right to health care is recognized by a number of groups. See, e.g., United Nations Universal Declaration of Human Rights, Art. 25, G.A. Res. 217(III), U.N. GAOR, 3d Sess., at 71-77 ("Everyone has the right to a standard of living adequate for the health and well-being of himself and of his family, . . . including medical care . . . "); AMERICAN ASSOC. OF RETIRED PERSONS, TOWARD A JUST AND CARING SOCIETY: THE AARP PUBLIC POLICY AGENDA 1991, at 96-97 (1991); American Medical Association in its statement to the Subcommittee on Health, Committee on Finance, United States Senate, July 29, 1988.

63 One ethically sound and rational basis for the allocation of truly scarce health care resources would be patient prognosis. 
We must recognize, however, that the problem of rapidly rising health care costs is a threat to our society's well-being, both in the present and future. Medical care is a sector of the economy that is largely unregulated by classic market forces. No such economic sector can grow disproportionately over time without disrupting other economic sectors. It is a problem that must be constructively and expeditiously addressed.

Cost-containment to date has been a piecemeal effort that has encouraged cost shifting. ${ }^{64}$ The general lack of success has inspired deep pessimism and cynicism about prospects for costcontainment. ${ }^{65}$ As an empirical matter, though, we have not tried every possible way to contain health care costs on a widescale basis for a significant period of time. ${ }^{66}$ A number of potentially useful ideas have been suggested, including promoting the widespread execution of advance directives, redoubling research efforts for diseases of old age, continuing the development and application of outcomes research, and many others. It will, however, take comprehensive health care reform-reform that will change both the way medicine is practiced and the way services are reimbursed-to achieve effective, long-term cost control. Only a comprehensively reformed system has the potential to eliminate system gaming efforts, to diminish inappropriate utilization of services, and to control the proliferation of medical technology. It is, therefore, comprehensive reform that should be the focus of our attention, not the ethically and economically unsound proposal to ration health care services for older Americans.

64 It is inaccurate to say that all cost-containment efforts have been abject failures. In 1983, the government implemented the Medicare prospective payment system nationwide, and in recent years Medicare, as a share of national health care expenditures, has declined. See Robert B. Friedland, Medicare: Meeting the Health Care Needs of the Elderly, IsSUE BRIEF (Public Policy Institute of the AARP, Washington, D.C.), July 1991, at 13. Private employers and insurers, however, have not enacted similar tough cost containment measures. If they made a concerted effort to contain costs, it is hardly certain that their effort would fail. See Uwe B. Reinhardt, Hotels and Airlines Do It: Why Not Hospitals?, WALL ST. J., Jan. 14, 1992, at Al4.

65 See Callahan, supra note 31, at 905 ; Wineskins, supra note 4 , at 8.

${ }^{66}$ See Wiener, supra note 1 , at 12. 


\section{.}

